\title{
Covid-19 Pandemic and the Market Performance Analysis: Evidence From Indonesia
}

\author{
Achmad Nurdany ${ }^{1}$, Muhammad Ghafur Wibowo ${ }^{1}$ \& Izra Berakon ${ }^{2}$ \\ ${ }^{1}$ Islamic Economic Department, Faculty of Islamic Economics and Business, Universitas Islam Negeri Sunan Kalijaga \\ Yogyakarta, Indonesia \\ 2 Islamic Finance Management Department, Faculty of Islamic Economics and Business, Universitas Islam Negeri \\ Sunan Kalijaga Yogyakarta, Indonesia \\ Correspondence: Achmad Nurdany, Islamic Economic Department, Faculty of Islamic Economics and Business, \\ Universitas Islam Negeri Sunan Kalijaga Yogyakarta, Indonesia.
}

Received: September 26, 2020

doi:10.5430/rwe.v11n6p337
Accepted: November 5, 2020

Online Published: December 20, 2020

URL: https://doi.org/10.5430/rwe.v11n6p337

\begin{abstract}
This paper empirically identified the impact of the Covid-19 pandemic on market performance in Indonesia. We use a cointegrating regression model of FM-OLS and D-OLS along with Cubic Spline missing data interpolation, summary unit root test, unit root test with Dickey-Fuller breakpoint selection, and Johansen cointegration test. Daily time series data of Covid-19 cumulative case, exchange rate, IDX composite, and gold commodity price were analyzed around 119 days after the first announced case in Indonesia. The finding from FM-OLS and D-OLS analysis showed that the Covid-19 pandemic has a positive and significant impact on exchange rate and gold commodity price. The Covid-19 pandemic impact is appeared to be negative and significant in explaining IDX composite price. It seems that during the Covid-19 pandemic, people prefer to do transactions in the commodity market than neither capital nor money market. The diagnostic of cointegrating regression showed that all variables are integrated of order one I (1), and the long-run cointegration among variables in each equation exists. From the unit root test with break point selection, this study revealed that Covid-19 pandemic has an extreme impact on Indonesian market performance only in the first month after the case was announced. The government responses to mitigate the spread of the Covid-19 pandemic and to minimize the possibly profound impact of market performance are appeared to be successful. Besides, it seems that people's fear is diminished, quite high in the first month, and began to shrink in the following month.
\end{abstract}

Keywords: Covid-19 pandemic, macroeconomic, cointegrating regression

JEL Classification: I150, E31, C32

\section{Introduction}

The Covid-19 pandemic was triggered at the end of 2019 in Wuhan, China. This pandemic was known SARS-CoV-2 for the first time and followed by 2019-nCoV (2019 novel coronavirus) after some research from the World Health Organization (WHO). The world now has an official name of this pandemic (Coronavirus Disease) Covid-19. The virus has already infected more than 12 million people in 213 counties and two international conveyances after approximately six months (Worldometer, 2020). The Covid-19 pandemic is the worst health crisis after the 1918 Spanish flu, which caused a profound loss of economical cost in history (Boissay \& Rungcharoenkitkul, 2020). Many countries prefer to implement physical distancing policy as well as locking down the entire city to mitigate the transmission of the virus. However, it causes a sudden stop in almost all sectors of economic activity. For example, in China, as the first country experienced Covid-19 break with a lockdown policy in January 2020, the Manufacturing Purchasing Manager's Index (PMI) falls for 22 points in the next two months. The fall of index indicates goods production decline and goods export drop from China to the rest of the world (UNCTAD, 2020).

The world is proven to have experienced much heavy pressure in history as a result of health crises in the form of epidemics, outbreaks, or pandemics. The 1918 Spanish Flu caused a 18\% decrease in global output of manufacturing sector (Correia, Luck, \& Verner, 2020), the SARS leads to a decrease of 50-60 percent Chinese international tourism revenue (Hai, Zhao, Wang, \& Hou, 2004), the H5N1 or the Avian Flu makes global GDP fall for up to 0.1\% (Burns, 
Mensbrugghe, \& Timmer, 2006), and the Ebola also has an impact on the loss of 25.2 billion GDP in West Africa (World Bank Group, 2014). The scale of the Covid-19 pandemic seems to be bigger than the previously health crisis cases occurred, therefore the Covid-19 pandemic will have a deeper impact on global economy, especially since the epicenter of the spread of the virus continues to expand. The epicenter of the spread of the corona virus at the time of writing this paper is no longer in China, but the United States, Brazil, India, Russia, Peru, Chile, United Kingdom and Mexico. Positive confirmed cases are also increasing day after day in these countries while in China there are almost no new cases found.

Covid-19 pandemic has a massive impact on the global economy, for example, the VIX index that reached the highest number over the past decade at 82.69 points on March 16th, 2020. The index measures the volatility of the US stock market derived from the S\&P 500® Index (SPXSM). It is one of the most popular daily indexes as a proxy of market indicators used by many financial media and recognized as a measure of volatility on a global basis. However, it is complicated to measure the real magnitude of the Covid-19 impact. Bebelow some of the researches and the impact concerns are explained:

Table 1. Global economic impact of Covid 19 pandemic

\begin{tabular}{|c|c|c|c|}
\hline $\begin{array}{l}\text { Geographical } \\
\text { Areas }\end{array}$ & $\begin{array}{l}\text { Impact } \\
\text { Concerns }\end{array}$ & $\begin{array}{l}\text { Study } \\
\text { Sources }\end{array}$ & Findings or projections \\
\hline \multirow{3}{*}{ Global } & $\begin{array}{l}\text { Economic } \\
\text { growth and } \\
\text { global trade }\end{array}$ & $\begin{array}{l}\text { Jackson, et al. } \\
(2020)\end{array}$ & $\begin{array}{l}\text { Global economic growth trims by } 2 \% \text { per month, and } \\
\text { global trade falls by } 13-32 \%\end{array}$ \\
\hline & $\begin{array}{l}\text { Economic } \\
\text { growth \& } \\
\text { trade }\end{array}$ & $\begin{array}{l}\text { Maliszewska, et al. } \\
(2020)\end{array}$ & $\begin{array}{l}\text { GDP falls by } 2 \text { percent for the world, } 2,5 \% \text { for } \\
\text { developing countries, and } 1,8 \% \text { for industrial } \\
\text { countries. }\end{array}$ \\
\hline & Employment & ILO (2020) & $\begin{array}{l}\text { Global unemployment increase between } 5,3 \text { million } \\
\text { in a low scenario and } 24,7 \text { million in high scenario } \\
\text { (base level } 188 \text { million in 2019) }\end{array}$ \\
\hline Asia Pacific & $\begin{array}{l}\text { Social and } \\
\text { economic }\end{array}$ & UNDP (2020) & $\begin{array}{l}\text { To preserve socio-economic impact, UNDP offers } \\
\text { US } \$ 500 \text { million to support } 100 \text { countries in the next } \\
\text { six months }\end{array}$ \\
\hline ASEAN & $\begin{array}{l}\text { Growth and } \\
\text { financial } \\
\text { market }\end{array}$ & ASEAN (2020) & $\begin{array}{l}\text { Growth revision varies from }-4 \% \text { in Singapore to } \\
6,5 \% \text { in Philipines. The financial market drops up to } \\
29.3 \% \text { in Vietnam. }\end{array}$ \\
\hline OECD & $\begin{array}{l}\text { Economic } \\
\text { growth }\end{array}$ & OECD (2020) & $\begin{array}{l}\text { Output level declines } 2 \% \text { per month with strict } \\
\text { containment measures, otherwise declines between } \\
4-6 \% \text { in output level. }\end{array}$ \\
\hline $\begin{array}{l}\text { Developing Asia } \\
\text { excludes PRC }\end{array}$ & Economic & ADB (2020) & $\begin{array}{l}\text { GDP loss for up to USD } 42,243 \text { million for the worse } \\
\text { scenario, USD } 22,284 \text { million for the moderate } \\
\text { scenario, and USD } 15,658 \text { million for the best case. }\end{array}$ \\
\hline
\end{tabular}

In Indonesia, the first Covid-19 case was reported in early March 2020. Since then, the number of cases has continued to increase exponentially. The inevitable impact of the Covid-19 pandemic on the Indonesian economy was also profound, especially in several weeks after the first announcement of the Covid-19 case by the government. Even though the government chose to implement a Large-Scale Social Distancing compared to the total lockdown, the economic impact remains very pronounced.

Bank Indonesia has reported a deficit of 344.7 million US dollars in Indonesia's Trade Balance in April 2020, whereas the previous month gained 715.7 million US dollars in surplus. The deficit could be influenced by massive decline of world demand or extensive disruption of the global supply chain. Indonesia's economic growth also appears to have slowed down to $2.97 \%$ in Q1 2020, whereas the previous quarter grew for up to $4.97 \%$ (year on year). The main factor is due to a sharp decline in domestic demand as a consequence of work -and everything- from home policies implementation. In order to anticipate the more profound economic impact of the Covid-19 
deployment, in June 2020, the government has re-opened various economic activities while continuing to apply a new-normal-standards strictly. With this new standard, the re-opening of economic activities starts from the principal essential sectors such as the industrial sectors, large companies, modern and traditional markets, and health services. The next step is to resume the cultural and educational activities. Finally, as the most deeply affected sector, the leisure economies (tourism, culinary, bar, café, gym, and restaurant) are only allowed to re-operate again at the final stage. It is expected that in early August 2020, all economic activities in Indonesia will be fully opened under the new normal standard with regular evaluations carried out.

The Covid-19 pandemic may also affect several economic indicators in Indonesia, directly or indirectly. Some examples are; the decline of stock prices along with the increase in its volatility, the fall of interest rates, the depreciation of the exchange rate, and the shrink of economic growth. Therefore, this study aims to examine the direct impact of the Covid-19 pandemic on the three leading economic indicators where all data are available daily, equally compared to the daily data in the confirmed case of covid-19. First is the money market indicator; this study uses the IDR/USD exchange rate. Second is the capital market indicator; this study employs a composite stock price index (IDX Composite). The third is a commodity market indicator; this study uses the price of the gold commodity per troy ounce. These indicators are expected to be able to describe the general condition of Indonesian market performance. The market performance data are available daily in real-time as well as the pandemic Covid-19 data so that the impact can be predicted early and measured accurately. To best of our finding, this is the first study that empirically discusses the impact of the Covid-19 pandemic toward the market performance in a developing country, especially in Indonesia.

\section{Literature Review}

In this session, the study discusses a variety of literature reviews that explain the phenomenon of health crises (epidemics, pandemics, or outbreaks) as a result of the deadly viruses rapidly spread in general and in particular Covid-19 virus along with their effects on a country's economy. Economic variables are not limited to the exchange rate, capital market index, or gold price as appeared in this study, considering that similar studies are scarce.

We began with the first recorded epidemic on history, the great influenza epidemic, also known as Spanish flu, occurred in 1918 -1920. Barro, Ursua, \& Weng (2020) mentioned in his paper, this epidemic has killed around 39 million people ( $2 \%$ of the population) and caused global consumption and global GDP to fall 6-8\%, respectively. Moreover, in some breath of World War I, the economic impact of the Spanish flu epidemic was very noticeably. Correia et al. (2020) then added that this epidemic also reduced manufacturing sector output for up to $18 \%$ due to declining global demand and supply.

When severe acute respiratory syndrome (SARS) occurred in Guangdong (China), which then spread to surrounding countries in November 2002, two years later, Hai et al. (2004) examined its short-term impact on the Chinese economy. They surveyed SARS impacts and whether what sectors were affected by the viruses. The result estimated that at the end of 2003, the international tourism sector revenue would decrease by $50-60 \%$ while domestic tourism would decrease by $10 \%$. The study also revealed that the estimation of the Chinese economy total loss reaching 25.3 billion US Dollars, while the economic growth was estimated to decrease by 1-2 percent. A decade later, China also encountered another outbreak of the H7N9 Influenza Virus in 2013. Qiu, Chu, Mao, \& Wu (2018) conducted a research in order to compare the impact of SARS and H7N9 on the Chinese economy and how the government should respond to the upcoming outbreaks that might occur in the future. The results showed that the two outbreaks had a significant negative effect on the economy, health, national security and international mobility. However, the socio-economic impact caused by H7N9 was not as serious as the impact caused by SARS. This could be happen because the government's response in tackling H7N9 spread is more effective, the government's openness in providing information is also more transparent.

In the case of another outbreak, Ebola, which occurred in several countries in Africa, also had a significant economic impact. Africa Research Bulletin (2014) states that the impact of Ebola on the countries of Guinea, Liberia \& Sierra Leone has caused an average loss of individual output for up to 809 million US dollars. Meanwhile, Jalloh et al. (2020) see that this outbreak also has an impact on the change in people's behavior. They found that the level of people's willingness to accept Ebola survival back to the community increased from $60 \%$ to $80 \%$. To note that Ebola cases have infected more than 14 thousand people with around 4000 deaths reported from mid-2014 to early 2016.

Then for the Middle East respiratory syndrome (MERS) outbreak, Jung \& Sung (2017) used the autoregressive integrated moving average method to detect the impact of the outbreak on offline and online sales in South Korea. Their results showed that offline sales of electronic goods decreased by $7.9 \%$ while online sales rose by $7.03 \%$. The author then concluded that this offline and online sales model for electronic goods could substitute one another. The 
researcher also illustrated that these findings could be taken into consideration for policymakers to deal with the possibility of a similar outbreak that happens in the future. Joo et al. (2019) added that the MERS outbreak was also estimated to cause a loss of 2.1 million foreign tourists who will potentially come to Korea. This loss was correlating with the loss of US $\$ 2.6$ billion from the tourism industry, approximately.

The most recent study in Indonesia, the Covid-19 pandemic, is expected to have an impact on increasing the poverty rate from 9.2\% in September 2019 to $9.7 \%$ by the end of 2020 (Suryahadi, Al Izzati, \& Suryadarma, 2020). The study also claims that the predicted number of infected people will reach 1.2 million people. That is the best and most efficient handling scenario. On the contrary, poverty will rise to $12.4 \%$, meaning that 8.5 million people will be labeled weak due to the Covid-19 pandemic at the end of this year. Furthermore, Qibthiyyah et al. (2020) added that the prediction of Indonesia's economic growth for 2020 would decline from 2.4 to $2.6 \%$ overall. The fiscal deficit will also widen by $5.07 \%$ of GDP. The study highlights a policy recommendation to the government to put an emphasis on tackling pandemic transmission in the short-term and recovering economic activity in the long term.

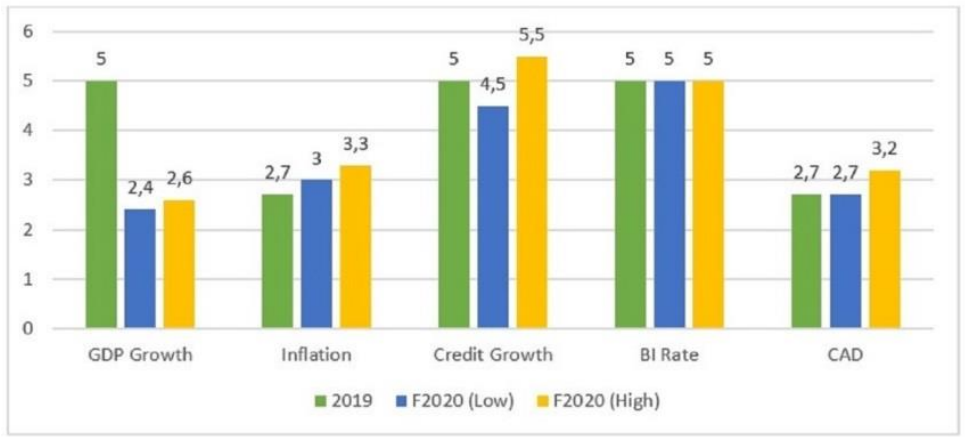

Figure 1. Indonesian economic forecast of Covid-19 impact

Source: LEPM FEB UI represented by (Qibthiyyah et al., 2020)

For that reason, S\&P Ratings, represented by Wood, Tan, \& Mok (Wood, Tan, \& Mok, 2020) as their credit analyst, affirmed BBB/A-2 ratings and revised to negative for Indonesia outlook. According to Apresian (2020), the Indonesian government needs to accentuate on increasing rapid test service, strengthening social distancing campaign, and distributing fast economic incentives accurately.

While the previous study of the pandemic history has been well-researched, relatively less is known on the empirical economic impact of the Covid-19 pandemic. Most studies focus only on the probability analysis as well as forecast projection. For example, in the early review of Boissay \& Rungcharoenkitkul (2020), who predicted that the global GDP in 2020 would be at the level of $-4 \%$ if the pandemic mitigation policy were prolonged? Other studies predicted that global GDP would decrease by 2\% each month (Jackson et al., 2020; Maliszewska et al., 2020; OECD, 2020), and global unemployment will rise to 5.3 million from 188 million bases in 2019 (ILO, 2020). Finally, the seven scenarios of McKibbin \& Fernando (2020), which predicted the macroeconomic impact of the Covid-19 epidemic is only labeled as another prediction. In this paper, there are no predictions, assumptions, forecasts, or scenarios. This paper will empirically identify the impact of the Covid-19 pandemic on market performance in Indonesia. The empirical analysis based on the daily historical data of the confirmed Covid-19 case and macroeconomic indicator of the money market, capital market, and commodity market.

\section{Method}

\subsection{Model Specifications}

In order to investigate the Covid-19 impact on Indonesian market performance, the empirical model in this study can be divided into three categories, namely exchange rates model as a proxy from the money market, stock price composite index model from the capital market, and gold prices model from the commodity market. The model can be specified as follows:

$$
\begin{aligned}
E R_{t} & =\beta_{0}+\beta_{1} C_{U M}+\varepsilon_{t} \\
I D X_{t} & =\beta_{0}+\beta_{1} C U M_{t}+\varepsilon_{t}
\end{aligned}
$$




$$
G O L D_{t}=\beta_{0}+\beta_{1} C U M_{t}+\varepsilon_{t}
$$

Where ER refers to exchanger rate; IDX is Indonesia stock exchange composite price; GOLD is gold commodity price; $\varepsilon_{t}$ is error term; and CUM is total confirmed case for the Covid-19 pandemic in Indonesia during the period of this study.

\subsection{Estimation Tehcniques}

This paper uses a cointegrating regression model from fully modified ordinary least square (FM-OLS) dan dynamic ordinary least square (D-OLS) analysis. Both models are appropriate analysis which in line with the type of data. FM-OLS estimation is proposed by Phillps and Hansen (1990) in order to employ a semi-parametric correction to solve the long-run correlation between the cointegration equation and stochastic regressors' innovation. The result of FM-OLS estimation is asymptotically unbiased and below the estimator is given by:

$$
\hat{\theta}=\left[\begin{array}{c}
\beta \\
\hat{\gamma}_{1}
\end{array}\right]=\left(\sum_{t=2}^{T} Z_{t} Z_{t}^{\prime}\right)^{-1}\left(\sum_{t=2}^{T} Z_{t} y_{t}^{+}-T\left[\begin{array}{c}
\lambda_{12}^{+\prime} \\
0
\end{array}\right]\right)
$$

Another key to FM-OLS is that the construction of covariance matrix estimator which can be described as $\widehat{\Omega}$ and $\widehat{\Lambda}$. And before the $\widehat{\Omega}$ and $\widehat{\Lambda}$ computation, here is the scalar estimator:

$$
\widehat{\omega}_{1.2}=\widehat{\omega}_{11}-\widehat{\omega}_{12} \widehat{\Omega}_{22}^{-1} \widehat{\omega}_{21}
$$

The interpretation of the Eq.5 can be explained as the estimated long-run covariance of $\mu_{1 t}$ conditional on $\mu_{2 t}$ with the degree of freedom correction $\widehat{\omega}_{1.2}$.

The process of eliminating the feedback of the cointegrating regression can also be done by building an asymptotically efficient estimator, which then widely known as Dynamic OLS/D-OLS (Saikkonen, 1992; Stock \& Watson, 1993). The D-OLS includes the lags and leads of $\Delta X_{t}$ that make error term become orthogonal to all sthocastic regressor innovations.

$$
y_{t}=X_{t}^{\prime} \beta+D_{1 t}^{\prime} \gamma_{1}+\sum_{j=-q}^{r} \Delta X_{t+j}^{\prime} \delta+v_{1 t}
$$

The presumption is that lags $(q)$ and leads $(r)$ of the $\mathrm{I}(1)$ regressor soaks up all of the long-run correlation between $u_{1 t}$ and $u_{2 t}$ so that the estimation of $\theta=\left(\beta^{\prime}, \gamma^{\prime}\right)^{\prime}$ have a similar asymptotic distribution with the previously explained model of FM-OLS.

These two analytical models can be applied to the series variable with equal non-stationary order I(1). We use a summary unit root test and unit root test with Dickey-Fuller breakpoint selection in order to specify the presence of unit root along with the break date of each independent variable. According to Sirag, SidAhmed, \& Ali (2018), who used the same estimation technique, to reduce the bias of OLS mainly as a result of simultaneity and endogenity problems, the FMOLS and DOLS use nonparametric and parametric corrections, respectively. This technique ensures that the timeseries model will be free from autocorrelation problem. Prior to the main estimation, this paper also use Cubic Spline data interpolation for the holiday and week-off missing data, summary unit root test, unit root test with Dickey-Fuller break point selection, and Johansen cointegration test.

\subsection{The Data}

This paper uses 119 daily time-series data from March $3^{\text {rd }}, 2020$, to June $30^{\text {th }}, 2020$, in order to investigate the impact of the covid-19 pandemic toward market performance in Indonesia. Daily data of the Exchange rate USD/IDR, Indonesian Stock Exchange (IDX) composite price and gold commodity price are used to be the independent variables. These variables represent each market, money, stock, and commodity. We then use the daily cumulative case of covid-19 pandemic data as an independent variable. The source of the data in this study varies from Bank Indonesia, Indonesia Stock Exchange, Indonesia Commodity and Derivatives Exchange, and Kawal Covid websites.

\section{Results and Discussions}

Most of the macroeconomic variables are non-stationary, so that there will be a high potential for spurious regression. The unit root test is carried out in order to identify the variable's order of integration. This study uses a summary unit root test from Levin, Lin \& Chu t; Im, Pesaran and Shin W-stat; Augmented Dickey-Fuller - Fisher; and Phillip Perron-Fisher. We previously employed data interpolation using the Cubic Spline model in order to fulfill the absence of exchange rate, IDX composite price, and gold commodity price data while in holiday or week offseason. Table 2 shows the results of the unit root summary. 
Table 2. Summary unit root test

\begin{tabular}{lllll}
\hline Unit root test Method & \multicolumn{1}{l}{ Level } & \multicolumn{1}{l}{$\mathbf{1}^{\text {st }}$ Difference } \\
\cline { 2 - 5 } & Statistic & Prob. & Statistic & Prob. \\
\hline Levin, Lin \& Chu t & 9.75682 & 1.0000 & -4.06039 & $0.0000^{*}$ \\
\hline Im, Pesaran and Shin W-stat & 3.43706 & 0.9997 & -9.48842 & $0.0000^{*}$ \\
\hline ADF - Fisher Chi-square & 12.4087 & 0.1339 & 133.640 & $0.0000^{*}$ \\
\hline PP - Fisher Chi-square & 8.78488 & 0.3608 & 123.845 & $0.0000^{*}$ \\
\hline
\end{tabular}

Notes: *significant at 5 percent level, respectively

The null hypothesis of summary unit root test asumes that there is a presence of common and individual unit root. The findings revealed that all variables are non-stationary at level, while at $1^{\text {st }}$ Difference, the variables are stationary. The probability value of each unit root test is below $5 \%(0,05)$ significant level. This study concludes that all variables are integrated of order one so that we can proceed to the cointegration test. We used standard Johansen (1988) cointegration test. The result showed the existence of a long-run cointegration relationship among variables in each equation. Table 3 explains the result of Johansen cointegration analysis.

Table 3. Johansen cointegration test

\begin{tabular}{clllll}
\hline Model & Hypothesized No. of CE(s) & Eigenvalue & Max-Eigen Statistic & 0.05 Critical Value & Prob.** \\
\hline \multirow{2}{*}{ Eqt. 1 } & None & At most 1 & \\
\cline { 2 - 6 } & At & 0.143262 & 17.93627 & 14.26460 & 0.0126 \\
\hline \multirow{2}{*}{ Eqt. 2 } & None $^{*}$ & 0.111870 & 13.76190 & 3.841466 & 0.0002 \\
\cline { 2 - 5 } & At most 1 & 0.129247 & 16.05408 & 14.26460 & 0.0258 \\
\hline \multirow{2}{*}{ Eqt. 3 } & None $^{*}$ & 0.065246 & 7.826742 & 3.841466 & 0.0051 \\
\cline { 2 - 5 } & At most 1 * & 0.171151 & 21.02436 & 14.26460 & 0.0037 \\
\hline
\end{tabular}

Note: * significant at 5 percent, respectively

The diagnostic of cointegrating regression FM-OLS and D-OLS model has been passed, where all variables are integrated of order one I(1) and long-run cointegration among variables in each equation exists. The finding from FM-OLS dan D-OLS analysis showed that the cumulative case of the covid-19 pandemic has a positive and significant impact on the exchange rate. The findings specify that a 1 percent increase in the cumulative case of the covid-19 pandemic will lead to an increase of 0.02-0.03 percent in the exchange rate. It can be concluded that the covid-19 pandemic has a significant impact on Indonesian Rupiah depreciation. The findings also revealed that the cumulative case of the covid-19 pandemic in Indonesia negatively affects the IDX composite price. The elasticity shows that a 1 percent increase in cumulative case of the covid-19 pandemic will lead to a decrease of 0.04 percent in the price of Indonesian stock exchange composite. This finding is in line with the global GDP decrease forecasted by (Jackson et al., 2020; Maliszewska et al., 2020; OECD, 2020).

Moreover, the cumulative case of the covid-19 pandemic appeared to be positive and significant in explaining the Indonesian gold commodity price. The coefficient of FM-OLS and D-OLS estimator indicates that a 1 percent increase in cumulative case of the covid-19 pandemic will lead to an approximately $0.02-0.03$ percent increase in gold commodity price. It seems that during the Covid-19 pandemic, people prefer to do transactions in the commodity market than neither capital nor money market. Table 4 shows the result of the cointegrating regression model using FM-OLS and D-OLS analysis. 
Table 4. The result of the cointegrating regression model (FM-OLS and D-OLS)

\begin{tabular}{|c|c|c|c|c|c|c|}
\hline & \multicolumn{3}{|l|}{ FM-OLS } & \multicolumn{3}{|l|}{ D-OLS } \\
\hline & Coef & t-Stat & Prob & Coef & t-Stat & Prob \\
\hline \multicolumn{7}{|c|}{ Eqt. 1 (Exchange Rate Model) } \\
\hline $\log (\mathrm{CUM})$ & 0.030728 & 8.466331 & 0.0000 & 0.029657 & 6.074526 & 0.0000 \\
\hline Intercept & 9.538072 & 515.9976 & 0.0000 & 9.553170 & 276.0423 & 0.0000 \\
\hline @Trend & -0.002902 & -11.03072 & 0.0000 & -0.002926 & -10.64222 & 0.0000 \\
\hline Adjusted- $\mathrm{R}^{2}$ & 0.808498 & & & 0.817229 & & \\
\hline \multicolumn{7}{|c|}{ Eqt. 2 (IDX Composite Model) } \\
\hline $\log (\mathrm{CUM})$ & -0.041229 & -6.608824 & 0.0000 & -0.044085 & -5.075408 & 0.0000 \\
\hline Intercept & 8.627553 & 271.5446 & 0.0000 & 8.652331 & 140.5245 & 0.0000 \\
\hline @Trend & 0.002895 & 6.403224 & 0.0000 & 0.002983 & 6.098681 & 0.0000 \\
\hline Adjusted-R ${ }^{2}$ & 0.588866 & & & 0.564498 & & \\
\hline \multicolumn{7}{|c|}{ Eqt. 3 (Gold Commodity Price Model) } \\
\hline $\log (\mathrm{CUM})$ & 0.031889 & 5.227513 & 0.0000 & 0.028639 & 3.589327 & 0.0005 \\
\hline Intercept & 16.90109 & 553.1533 & 0.0000 & 16.93667 & 301.7142 & 0.0000 \\
\hline @Trend & -0.002003 & -4.382109 & 0.0000 & -0.001954 & -4.215084 & 0.0001 \\
\hline Adjusted- $\mathrm{R}^{2}$ & 0.505066 & & & 0.536861 & & \\
\hline
\end{tabular}

Based on Table 4, in order to compare between Eqt.1, Eqt.2, and Eqt.3, we then used the adjusted $\mathrm{R}^{2}$ to choose the best one. The result indicated that the exchange rate model from the Eqt. 1 has the highest adjusted $\mathrm{R}^{2}$ value, followed by the IDX composite and gold commodity price model. The finding of our study showed that during this pandemic, covid-19 cumulative case could explain more than 80 percent to the exchange rate. While Te rest, the cumulative case of a covid-19 pandemic can predict the IDX composite dan the gold commodity price, respectively, each at 56-58 percent and 50-53 percent.

Finally, in order to ensure the existence of a structural break that cannot be detected by the previous summary unit root test, we employe unit root test with breakpoint introduced by Perron (1997). We use the unit root test with Dickey-Fuller breakpoint selection. This test is aimed to identify whether the macroeconomic impact of the co-19 pandemic has a break date point, especially from the exchange rate, IDX composite, and gold price variable. Table 5 shows the possibility of an endogenous structural break in the series.

Table 5. Unit root test with breakpoint

\begin{tabular}{lll}
\hline Unit root test with Dickey-Fuller breakpoint selection & Break date \\
\hline \multirow{2}{*}{ Exchange Rate } & Level & April $27^{\text {th }}, 2020$ \\
& $1^{\text {st }}$ Difference* & March $20^{\text {th }}, 2020$ \\
\hline \multirow{2}{*}{ IDX Composite } & Level & May $27^{\text {th }}, 2020$ \\
& $1^{\text {st }}$ Difference* & March $26^{\text {th }}, 2020$ \\
\hline \multirow{2}{*}{ Gold Price } & Level & March $19^{\text {th }}, 2020$ \\
& $1^{\text {st }}$ Difference* & March $25^{\text {th }}, 2020$ \\
\hline
\end{tabular}

Notes: *significant at 5 percent level, respectively

Since the null hypothesis of the variables unit root test with the structural breakpoint is failed to reject at level, we proceed with the break at $1^{\text {st }}$ Difference. The results show that all variables have a break date point at the end of 
March 2020. Each break date for the exchange rate, IDX Composite, and gold price is 20th, 27th, and 25th of March 2020. These findings indicate that Indonesian market performance reacts extensively to the covid-19 case only in the first month after the covid-19 case was discovered. Figure 2 can better explain these findings.

Cumulative case of the Covid-19 pandemic in Indonesia grew exponentially from only two people on March $2^{\text {nd, }}$ 2020 , to more than 56 thousand positive cases on June $30^{\text {th, }} 2020$. However, the growth of the Covid-19 case has an impact on Indonesian market performance in general. If we take a zoom only on the three leading indicators for which data are available daily, the cumulative case of the covid-19 pandemic gives an extreme reaction to the market performance only in the first month after the first case is found.

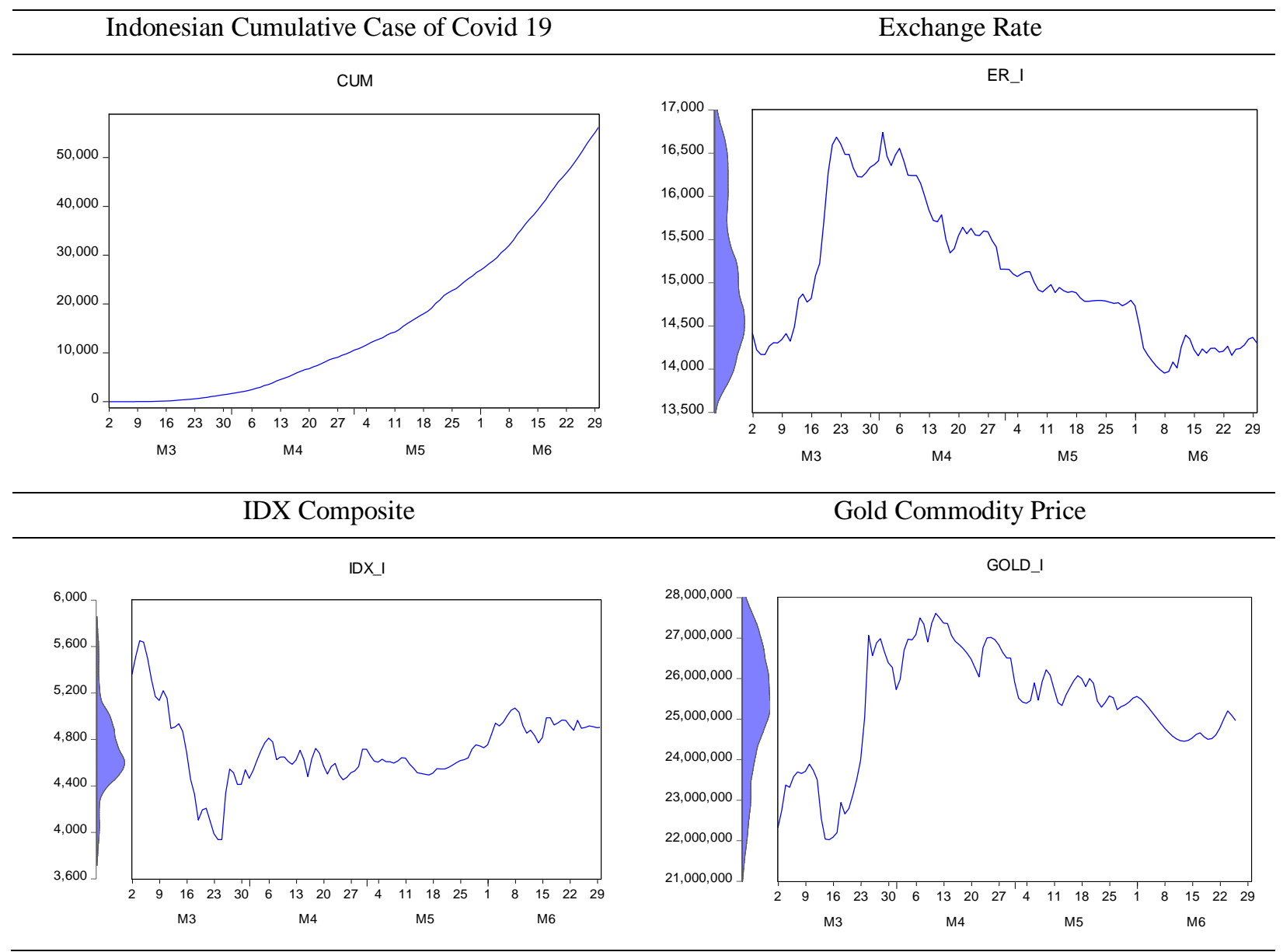

Figure 2. Indonesian cumulative case of Covid-19 and its macroeconomic impact

This study concluded that the cumulative case of the Covid-19 pandemic has an extreme impact on Indonesian market performance only in the first month after the case was announced. The impact began to wane in the following month. This diminishing impact could be due to the successful implementation of the government response to mitigate the spread of the Covid-19 pandemic also in some breath to minimize the possibly profound impact of market performance. The government policies are increasing health budget, removing taxes for the SMEs, restructuring credit payment for businesses and industries, eliminating all or reducing some of electricity bill payments, and cash transfers to the directly affected people. Besides, it seems that people's fear was also diminished, quite high in the first month, and began to shrink in the following month. The people are now ready to live under the new normal standard life.

\section{Conculsions}

World history is proven to have experienced much heavy pressure as a result of health crises, epidemics, outbreaks, or even pandemics. The impact scale of the Covid-19 pandemic seems to be bigger than the previously occurred 
health crisis cases. Therefore, the Covid-19 pandemic will have a more profound impact on the global economy, especially since the epicenter of the spread of the virus continues to expand. While the previous study of the pandemic history has been well-researched, relatively less is known on the empirical economic impact of the Covid-19 pandemic. Most studies are focused only on the probability analysis as well as forecast projection. This paper has empirically identified the impact of the Covid-19 pandemic on market performance in Indonesia. The empirical analysis based on the daily historical data of the confirmed Covid-19 case and macroeconomic indicator of the money market, capital market, and commodity market.

This paper uses a fully modified ordinary least square (FM-OLS) dan dynamic ordinary least square (D-OLS) cointegrating regression model along with Cubic Spline missing data Interpolation, Summary Unit root test, unit root test with Dickey-Fuller breakpoint selection, and Johansen cointegration test. Daily time series data of Covid-19 cumulative case, exchange rate, IDX composite, and gold commodity price are used from March $3^{\text {rd }}$, 2020, to June $30^{\text {th }}, 2020$, in order to investigate the impact of covid-19 pandemic toward market performance in Indonesia.

The finding from FM-OLS and D-OLS analysis showed that the cumulative case of the Covid-19 pandemic has a positive and significant impact on the exchange rate and gold commodity price. The Covid-19 pandemic impact is appeared to be negative and significant in explaining IDX composite price. It seems that during the Covid-19 pandemic, people prefer to do transactions in the commodity market than neither capital nor money market. The diagnostic of cointegrating regression showed that all variables are integrated of order one I(1), and the long-run cointegration among variables in each equation exists. From the unit root test with break pint selection, this study revealed that the cumulative case of the Covid-19 pandemic has an extreme impact on Indonesian market performance only in the first month after the case was announced. The government responses to mitigate the spread of the Covid-19 pandemic and to minimize the possibly profound impact of market performance are appeared to be successful. Our suggestion for possible future research is to incorporate the prediction analysis that provides better recommendation for the policy-maker. Besides, it seems that people's fear is diminished, quite high in the first month, and began to shrink in the following month.

\section{References}

ADB. (2020). The economic impact of the COVID-19 outbreak on developing Asia. ADB Briefs No.128, 9(128), 1-14. https://doi.org/10.22617/BRF200096

Apresian, S. R. (2020). Responding to the COVID-19 outbreak in Indonesia: lessons from European countries and South Korea. Jurnal Ilmiah Hubungan Internasional, 2019, 53-57. Retrieved from http://journal.unpar.ac.id/index.php/JurnalIlmiahHubunganInternasiona/article/view/3868

ARB. (2014, November). Ebola Crisis: Worsening Economic Impact. Africa Research Bulletin: Economic, Financial and Technical Series, 20547A-20549C. https://doi.org/10.1111/j.1467-6346.2014.06012.x

ASEAN. (2020, April ). Economic impact of Covid-19 outbreak on ASEAN. Asean Policy Brief, 1-17. Retrieved from https://asean.org/storage/2020/04/ASEAN-Policy-Brief-April-2020_FINAL.pdf

Barro, R. J., Ursua, J. F., \& Weng, J. (2020). The coronavirus and the great influenza pandemic: lessons from the "Spanish Flu" for the coronavirus's potential effects on mortality and economic activity. CESifp Working Paper Series No. 8166, March, 25. Retrieved from https://www.ifo.de/DocDL/cesifo1_wp8166.pdf

Boissay, F., \& Rungcharoenkitkul, P. (2020). Macroeconomic effects of Covid-19: an early review. BIS Bulletin, (7), 9. Retrieved from https://www.bis.org/publ/bisbull07.htm

Burns, A., Mensbrugghe, D. V. D., \& Timmer, H. (2006, June). Evaluating the economic consequences of avian influenza. The World Bank, 5, 1-6. https://doi.org/10.1017/CBO9781107415324.004

Correia, S., Luck, S., \& Verner, E. (2020). Pandemics depress the economy, public health interventions do not: evidence from the 1918 Flu. SSRN Electronic Journal. https://doi.org/10.2139/ssrn.3561560

Hai, W., Zhao, Z., Wang, J., \& Hou, Z.-G. (2004). The short-term impact of SARS on the chinese economy. Asian Economic Papers, 3(1), 57-61. https://doi.org/10.1162/1535351041747905

ILO. (2020, March). COVID-19 and the world of work: Impact and policy responses. ILO Monitor 1st Edition, 1-15. Retrieved from http://hdl.voced.edu.au/10707/533608

Jackson, J., Weiss, M. A., Schwarzenberg, A. B., \& Nelson, R. M. (2020, June). Global Economic Effects of COVID-19. Congressional Research Service, (4). Retrieved from https://crsreports.congress.gov

Jalloh, M. F., Sengeh, P., Bunnell, R. E., Jalloh, M. B., Monasch, R., Li, W., ... Morgan, O. (2020). Evidence of 
behaviour change during an Ebola virus disease outbreak, Sierra Leone. Bulletin of the World Health Organization, 98(5), 330-340B. https://doi.org/10.2471/BLT.19.245803

Johansen, S. (1988). Statistical analysis of cointegration vectors. Journal of Economic Dynamics and Control, 12(2-3), 231-254. https://doi.org/10.1016/0165-1889(88)90041-3

Joo, H., Maskery, B. A., Berro, A. D., Rotz, L. D., Lee, Y. K., \& Brown, C. M. (2019). Economic impact of the 2015 MERS outbreak on the Republic of Korea's tourism-related industries. Health Security, 17(2), 100-108. https://doi.org/10.1089/hs.2018.0115

Jung, E., \& Sung, H. (2017). The influence of the Middle East respiratory syndrome outbreak on online and offline markets for retail sales. Sustainability (Switzerland), 9(411), 1-23. https://doi.org/10.3390/su9030411

Maliszewska, M., Mattoo, A., \& Mensbrgghe, D. (2020, April). The potential impact of COVID-19 on GDP and trade A preliminary assessment. Policy Research Working Paper, 9211, 1-24. Retrieved from https://openknowledge.worldbank.org/handle/10986/33605

McKibbin, W. J., \& Fernando, R. (2020, February). The global macroeconomic impacts of COVID-19: seven scenarios. SSRN Electronic Journal. https://doi.org/10.2139/ssrn.3547729

OECD. (2020, April). Evaluating the initial impact of COVID-19 containment measures on economic activity. Tackling Coronavirus (COVID-19) Contributing to a Global Effort, 1-6. Retrieved from https://read.oecd-ilibrary.org/view/?ref=126_126496-evgsi2gmqj\&title=Evaluating_the_initial_impact_of_COV ID-19_containment_measures_on_economic_activity

Perron, P. (1997). Further evidence on breaking trend functions in macroeconomic variables. Journal of $\begin{array}{lllll}\text { Econometrics, } & 80, & 355-385 & \text { Retrieved } & \text { from }\end{array}$ https://www.sciencedirect.com/science/article/abs/pii/S0304407697000493

Phillips, P. C. B., \& Hansen, B. E. (1990). Statistical inference in instrumental variabls regression with I(1) processes. Review of Economic Studies, 57, 99-125. Retrieved from https://www.ssc.wisc.edu/ bhansen/papers/restud_90.pdf

Qibthiyyah, R. M., Sabrina, S., Desdiani, N. A., Rifky, T., Cesarina, A., \& Husna, M. (2020). Enduring the COVID-19 pandemic crisis. Macroeconomic Analysis Series Indonesia Economic Outlook, Q2, 1-16. Retrieved from http://bit.ly/LPEMCommentarySubscription

Qiu, W., Chu, C., Mao, A., \& Wu, J. (2018). The impacts on health, society, and economy of SARS and H7N9 outbreaks in China: a case comparison study. Journal of Environmental and Public Health. https://doi.org/10.1155/2018/2710185

Saikkonen, P. (1992). Estimation and testing of cointegrated systems by an autoregressive approximation. Econometric Theory, 8(1), 1-27. https://doi.org/10.1017/S0266466600010720

Sirag, A., SidAhmed, S., \& Ali, H. S. (2018). Financial development, FDI and economic growth: evidence from

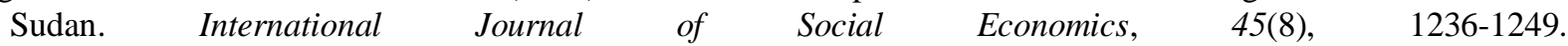
https://doi.org/10.1108/IJSE-10-2017-0476

Stock, J. H., \& Watson, M. W. (1993). A simple estimator of cointegrating vectors in higher order integrated system. Econometrica, 61(4), 783-820. Retrieved from https://www.ssc.wisc.edu/ bhansen/718/StockWatson1993.pdf

Suryahadi, A., Al Izzati, R., \& Suryadarma, D. (2020, April). The impact of COVID-19 outbreak on poverty: an estimation for Indonesia (Draft). SMERU Working Paper, 1-20. Retrieved from http://smeru.or.id/en/content/impact-covid-19-outbreak-poverty-estimation-indonesia

UNCTAD. (2020, March). Glonal trade impact of the Coronavirus (COVID-19) epidemic. Retrieved from https://unctad.org/en/PublicationsLibrary/ditcinf2020d1.pdf

UNDP. (2020, April). The social and economic impact of Covid-19 in the Asia-Pacific region. Position Note Prepared by UNDP Regional Bureau for Asia and the Pasific, 1-36. Retrieved from https://www.undp.org/content/undp/en/home/librarypage/crisis-prevention-and-recovery/the-social-and-econom ic-impact-of-covid-19-in-asia-pacific.html

Wood, A., Tan, K., \& Mok, R. (2020, April). Indonesia outlook revised to Negative as COVID-19 hits fiscal, external metrics; "bbb/a-2" ratings affirmed. $S \& P$ Global Ratings, 1-10.

World Bank Group. (2014). The economic impact of the 2014 ebola epidemic: chort and medium term estimates for 
West Africar from http://documents.worldbank.org/curated/en/524521468141287875/pdf/912190WP0see0a00070385314B00PUB LIC0.pdf

Worldometer. (2020). Word Meter Coronavirus. Retrieved June 4, 2020, from https://www.worldometers.info/coronavirus/

\section{Copyrights}

Copyright for this article is retained by the author(s), with first publication rights granted to the journal.

This is an open-access article distributed under the terms and conditions of the Creative Commons Attribution license (http://creativecommons.org/licenses/by/4.0/). 